\title{
PAULO FREIRE
}

(1921 1997)

\author{
»SVETA NE SMEMO SPREJEMATI TAKEGA, KOT \\ JE. MORAMO BITI RAZLIČNI, DA USTVARIMO \\ NEKAJ DRUGAČNEGA NA TEM SVETU. «
}

(Paulo Freire, decembra 1996)

P Paulo Freire. Nekateri so ga celo jemali kot merilo strokovnosti $\mathrm{v}$ določeni instituciji ali državi. Spominjam se komisije Združenih narodov, ki je v začetku osemdesetih let ocenjevala stanje šolstva $\mathrm{v}$ Jugoslaviji in na veliko začudenje ugotovila, da pedagogi sploh ne poznajo Paula Freira. To se jim je zdelo tako pomembno, da so to $\mathrm{v}$ poročilu o obisku posebej poudarili.

Freire je zaslovel zlasti s knjigo Pedagogika zatiranih (Pedagogy of the Oppressed), ki jo je napisal, ko je bil profesor na harvardski univerzi (1969).

Knjiga je bralca osupnila, vsak jo je prebral na dušek. Pisana je bila zelo jasno, čeprav je obravnavala temeljne paradigme vzgoje in izobraževanja odraslih. Po španskem izvirni$\mathrm{ku}$ je bila prevedena skoraj v vse svetovne jezike in večkrat ponatisnjena. Še danes jo imajo za nekakšen katekizem teorije o izobraževanju odraslih.

Paulo Freire se je rodil leta 1921 v družini srednjega sloja v Recifu v Braziliji. Ko je bil še majhen deček, je družina obubožala in znašli so se med največjimi reveži - poljskimi delavci na plantažah. Tako je spoznal dve plati življenja: udobje in bedo. To ga je spremljalo vse življenje. Boril se je, da bi bilo revnim bolje, da bi bili sposobni svet obravnavati kritično in ga spreminjati. Kmalu po diplomi na pravu se je posvetil izobraževanju. Leta 1959 je doktoriral iz andragogike na univerzi Redclife in postal $\mathrm{v}$ šestdesetih letih prvi direktor izrednega študija na tej univerzi. Svojim študentom je predaval o moči znanja, pomenu sposobnosti pisanja in branja. Zagovarjal je stališče, da se morajo ljudje na podeželju naučiti mnogo več, ne pa samo pisati in brati. Sposobni morajo biti uravnavati svoje življenje in ne smejo prepustiti, da drugi odločajo o njih.

Dosledno je razvijal posebno metodiko opismenjevanja poljskih delavcev. Učenje je povezoval z ozaveščanjem in razvijanjem sposobnosti. Na seminarjih so obravnavali dejanske razmere na vasi, usodo posamezne družine ali človeka. Izobraževanje je do skrajnosti približal ljudem. Trdil je, da učbenikov za izobraževanje odraslih ni mogoče pisati, ker se vsakokrat spreminja vsebina, čeprav obravnavajo enak pojav ali proces. Znano je, da je sam in tudi njegovi učenci pripravljal učno gradivo za vsako skupino posebej. Freirova metodika opismenjevanja ljudi se je razširila na vse kontinente. Intenzivno so jo uporabljali v Južni Afriki med črnci, v Aziji in drugje. Andragogi so jo preučevali kot posebno doktrino in napisali o njej precej disertacij in magistrskih nalog na raznih univerzah povsod po svetu.

Med vojaškim pučem so ga zaprli in nato izgnali iz Brazilije. Živel je v izgnanstvu v Švici pri Svetovnem svetu cerkva, od koder je sodeloval $\mathrm{z}$ neodvisnimi afriškimi in azijskimi $\mathrm{dr}$ žavami. Deloval je tudi v Čilu, vendar mu po atentatu na Allendeja, predsednika države in velikega humanista, tudi tam niso bile razmere naklonjene. Precej je sodeloval s tanzanijskim predsednikom in uglednim učiteljem Niererejem.

Prvič sem ga srečala na svetovnem kongresu za izobraževanje odraslih v Dar-es-Salamu leta 1976. Prvi vtis o njem me je presenetil. V nasprotju z njegovimi knjigami, ki so bile polne naboja, ognja in moči in ki so silovito prepričevale bralca o pravi poti izobraževanja, je 


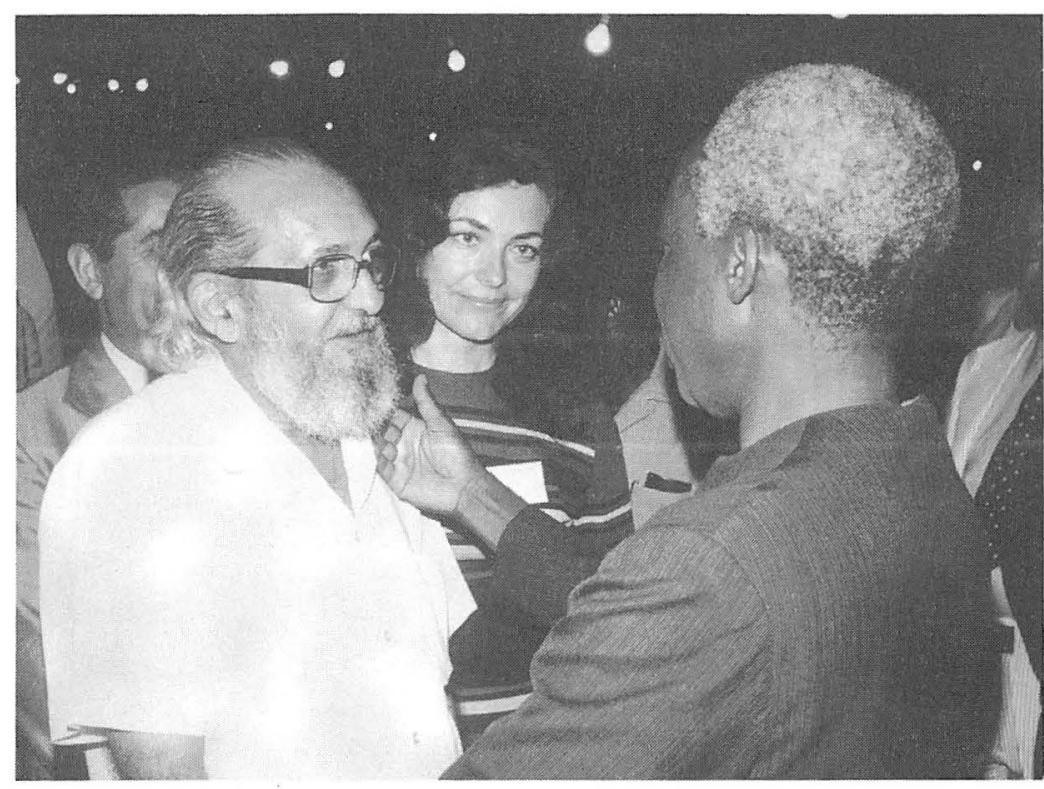

Svetovni kongres za izobraževanje odraslih leta 1976 v Dar-es-Salamu. Od leve proti desni: Paulo Freire, Ana Krajnc, Julius Nierere

Freire osebno deloval mirno, tiho in zadržano, s stalnim nasmeškom na obrazu in dobrohotnimi kretnjami. Najprej sem težko uskladila oboje. Šele pozneje sem ugotovila, da je o svojih stališčih in svoji strokovni teoriji tako prepričan, da mu zunanja vehemenca in glasna obramba ni potrebna. Zato sem ga še bolj občudovala. Večer, ki sem ga preživela v pogovoru z njim, s Kiddom in z Niererejem, mi je ostal za večno $v$ spominu. Vsi trije veliki humanisti in zagovorniki demokratične vzgoje so oblikovali in zaznamovali moje strokovne poglede.

Po amnestiji leta 1979 se je vrnil v Brazilijo in postal profesor na univerzi v Sao Paulu ter bil leta 1988 tudi minister za izobraževanje mesta Sao Paula. Z veliko odgovornostjo je reformiral večino državnih šol v Braziliji. Od leta 1985 do svoje smrti je bil častni predsednik Mednarodnega sveta za izobraževanje odraslih s sedežem $v$ Torontu (ICAE) in veliki prijatelj ter animator mnogih andragogov povsod po svetu.

Napisal je precej knjig. Naj jih omenim nekaj, ki so izšle v zadnjih letih: Pedagogika upanja (Pedagogy of Hope), 1992; Oživljanje pedagogike zatiranih (Reliving Pedagogy of the Oppresed), 1993; Pisma Kristini: razmišljanje o mojem življenju in delu (Letters to Cristina: Reflections on my Life and Work), 1996.
Paulu zaradi srčnega infarkta. Vest o njegovi smrti nas je vse prizadela in presenetila, saj smo imeli vedno občutek, da bo zmeraj pričujoč, v oporo vsakemu, ki ga potrebuje. Zapustil pa nam je svoje misli in prepričanje, ki so zapisani v knjigah. Slava mu!

V Sloveniji za zdaj, kljub poskusom, še vedno nimamo prevedene nobene njegove knjige, niti Pedagogike zatiranih. Tudi edini izvod v knjižnici oddelka za pedagogiko in andragogiko je izginil, kar me niti ne preseneča. Ali smo v Sloveniji še tako daleč od humanističnega pristopa k vzgoji in izobraževanju?

dr. Ana Krajnc 